\title{
PLAY THERAPY TO REDUCE ANXIETY IN CHILDREN
}

1.2. Wahyu Endang Setyowati, ${ }^{3 .}$ Moses Glorino Rumambo Pandin, Dr. M.Si., M.Phil., M.Psi., Psikolog

1. Student of Doctoral in Nursing, Faculty of Nursing, Airlangga University

2. Faculty of Nursing, Sultan Agung Islamic University

${ }^{3 .}$ Department of English Literature, Faculty of Humanities, Airlangga University

\section{Email : wahyu.endang.setyowati-2020@fkp.unair.ac.id}

\begin{abstract}
Play therapy is an approach to providing assistance in overcoming problems using media such as toys, art media, games, and communication. The purpose of this paper is to find out that play therapy can reduce anxiety in children. The research design used in this study was a study-literature review. The data used in this research comes from the results of research that have been conducted and published in national and international online journals. The method of analysis used in this study is the PRISMA (Preferre Reporting Items for Systematic Reviews and Meta Analysis) method.
\end{abstract}

Keywords: play therapy, anxiety, children.

\section{CHAPTER I}

\section{INTRODUCTION}

\section{A. Background}

Childhood is one of the most important periods in a person's life (Novia \& Arini, 2021). The majority of children in their childhood often experience psychological disorders which are caused by a lack of attention and guidance in their development process (Zamani et al., 2020). Psychological disorders that occur in these children include depression, anxiety, bullying, and so on. 
Anxiety is a psychological disorder characterized by feelings of anxiety or worry, fear, refusing treatment, which can cause children to react like crying and stress (Parwata \& Rantesigi, 2020). This is part of normal development. However, if the child's response to anxiety is excessive, it will have an impact on the child's healing and development process (Parwata \& Rantesigi, 2020). By giving this intervention, it can reduce anxiety.

The right intervention in dealing with children's anxiety is Play therapy. Play therapy is one of the nursing interventions that nurses can do independently in dealing with anxiety problems in children (Parwata \& Rantesigi, 2020). The types of play therapy in the last decade are roleplaying therapy, playing plasticine, coloring games, storytelling, and several other play therapies.

Play therapy is very easy and proven effective in reducing children's anxiety levels. Based on the results of the research by Alini (2017), it was stated that there is an effect of playing plasticine therapy on the anxiety levels of children aged 3-6 years. This is supported by the research of Stulmaker \& Ray (2015)which stated that intervention with Child-Centered Play Therapy / CCPT can effectively reduce anxiety levels because it can make children independent (Stulmaker \& Ray, 2015a).

CCPT helps in fostering greater self-esteem with a more integrated self-structure. Theoretically, children are in safe relationships with play therapists (Stulmaker \& Ray, 2015a). The play therapy characterized by conformity, empathy, and unconditional positive attention will be more 
receptive to children parts and their experiences that they have denied, including fear and anxiety (Urban et al., 2020).

Therapeutic functions in play therapy according to (Parwata \& Rantesigi, 2020), include facilitating verbal and nonverbal communication in handling fear and anxiety during child recovery, providing entertainment, helping children feel safer against foreign environments, reducing separation stress, encouraging interaction, and developing positive attitudes towards others. Thus, with this therapeutic function, anxiety problems in children can be resolved.

\section{B. Formulation of the problems}

Play therapy is one of the simple nursing interventions carried out independently by nurses in dealing with children's anxiety problems to increase self-esteem and reduce levels of anxiety and worry. Based on the description of the background, the formulation of the problem is "How does the implementation of play therapy reduce anxiety in children?"

\section{Purposes}

\section{General Purpose}

This paper was written to figure out and understand how the implementation of play therapy to reduce anxiety in children.

\section{Specific Purpose}

a. To figure out the definition of play therapy to reduce anxiety in children, 
b. To figure out the benefits of play therapy to reduce anxiety in children,

c. To figure out the implementation of play therapy to reduce anxiety in children. 


\section{CHAPTER II}

\section{LITERATURE REVIEW}

\section{A. A. The definition of play therapy to reduce anxiety in children}

Play therapy is an approach to provide assistance to overcome problems by using media such as toys, art media, games, and communication (Novia \& Arini, 2021.). Play therapy is also a systematic way in accordance with the theory, which is used for the independence of a trained therapist, using a variety of games, which have the ultimate goal of helping clients to prevent or even overcome their problems and develop optimally (Novia \& Arini, 2021).

Playing is one of the means to stimulate children's growth and development so that they can grow and develop optimally. Here, the play equipment used should be adapted to the children's age (Suryadi, 2017). In play therapy, the method used is a cognitive method, namely problem solving by telling stories, which of course is assisted by the aforementioned game tools. The use of play therapy itself is to help children who have emotional problems, anxiety due to stress, pressure, or depression so that these feelings can be reduced and the children are expected to be able to deal with their problems beforehand.

\section{B. The benefits of play therapy to reduce anxiety in children}

Playing activities are not only carried out by healthy children, but even sick children also need it, especially when they are experiencing 
anxiety (Parwata \& Rantesigi, 2020). When you are in an anxious state, the need to play is very much needed as a distraction or diversion therapy (Parwata \& Rantesigi, 2020). Concerning play therapy used to reduce the anxiety felt by children, games can also be given because games played with children can become a therapy or called as play therapy (Parwata \& Rantesigi, 2020). Play therapy can be used as a medium for psychotherapy or treatment for children (Parwata \& Rantesigi, 2020).

Garcia \& O'neil (2020) explained that play therapy and good family cooperation can minimize or reduce anxiety or stress in children. Through play, children can express thoughts, feelings, fantasies, and creative power while still developing their creativity and adapting more effectively to various sources of stress (Garcia \& O'Neil, 2021). Children need to play to release the fear and anxiety they experience as coping in dealing with stress (Ünver et al., 2020). The purpose of playing in principle is to be able to continue the growth and development phase optimally, develop children's creativity, and adapt more effectively to stress (Stulmaker \& Ray, 2020).

Playing is one of the fun activities for children (Garcia \& O'Neil, 2021). Playing activities are not only positive for mental health but also as an effective medium for learning (Garcia \& O’Neil, 2021)). Playing is a medium for reflection, self-introduction through a process of deep experience with play media such as houses, dolls, animal figures, and others (Ortiz et al., 2020).

\section{The implementation of play therapy to reduce anxiety in children}


In implementing play therapy, several steps must be taken by the counselor (Zengin et al., 2020), including:

1. Selection of instruments

In most play therapy applications, generally, it uses toys. The selection of toys that will be used in the therapy process must also consider the characteristics of the client who will receive therapy and the goals of the therapy itself. The use of supporting media also needs to be considered in the therapy process.

2. Describing the therapeutic process

Previously, the therapy process also needed to be informed to related parties such as parents and teachers. This will provide a separate understanding and can even lead to situations that support the success of the therapy process itself. Sometimes the action plan also needs to be notified to the children as the client.

3. The initiation stage

The initiation stage usually occurs during the initial sessions of the meeting. The therapist needs to reassure the client that the ongoing process will be very enjoyable and can help overcome what he is feeling and create a "frequency" that is common with the child.

4. Ending the session

There are several views on ending each session of the meeting. The therapist can clean up all residual activities that have been done, especially if the client is still very young. However, there is an opinion 
which states that the therapist should also clean up the remaining activities with the client because it will raise and strengthen the relationship between the therapist and the client.

5. Observing the client's development

After the session ends, it does not mean that the therapist's work is finished. Sometimes in some cases, the child will show different characteristics between his attitude with his parents and his natural environment, with the attitude when he is with the therapist. The goal of therapy is to change the client's behavior, thoughts, attitudes, and attitudes both during therapy sessions and in everyday life.

6. Reporting sessions

At the end of each session, the therapist must make notes of everything that happened during the given intervention session. This can be used as a record for both the therapist and the client himself. Sometimes in the next session the changes that have occurred in the past meeting will not appear again, so the client needs to be reminded again of everything that has happened to him.

7. Completing the session

Between the therapist and the client must have an agreement in advance about the therapeutic process. When the intervention session will end, there must be consideration from both parties. If the client is still considered unable to make a decision to end the therapy, the 
therapist can do this by himself, or by asking for input from related parties, such as parents. 


\section{CHAPTER III \\ RESEARCH METHOD}

\section{A. Research Design}

This research is research using the literature study method or literature review. The literature review can be obtained from various sources including journals, books, documentation, the internet, and libraries. The literature review method is a series of activities related to methods of collecting library data, reading and taking notes, and managing writing materials (Nursalam, 2016). The type of writing used is a literature review of a study that focuses on the results of writing related to the topic or variable of writing.

\section{B. Data Collection Technique}

The data used in this research comes from the results of research that have been conducted and published in national and international online journals. In conducting this research, the researchers searched for research journals published on the internet using the Ebsco host search engine and clinical keys, with keywords: play therapy, anxiety, children.

Table 3.1 The inclusion criteria for this literature are:

\begin{tabular}{l|l}
\hline Criteria & Inclusion \\
\hline Problem & $\begin{array}{l}\text { International journals from different databases } \\
\text { and related to research variables }\end{array}$ \\
\hline Intervention & Play Therapy \\
\hline Comparison & No comparison \\
\hline
\end{tabular}




\begin{tabular}{l|l}
\hline Outcome & $\begin{array}{l}\text { The effect of play therapy on reducing anxiety } \\
\text { in children }\end{array}$ \\
\hline Design & Qualitative, quantitative, pre-experimental dan \\
& Systematic/Literature review \\
\hline Period & Articles published from 2017 to 2021 \\
\hline Language & English and Indonesian \\
\hline Type of Article & Full text article \\
\hline Topic & Play therapy to reduce anxiety in children \\
\hline
\end{tabular}

After collecting data through the database, the researchers used the PRISMA (Preferred Reporting Items for Systematic Reviews and MetaAnalysis) method to get the desired articles to be researched which are described in the chart below:
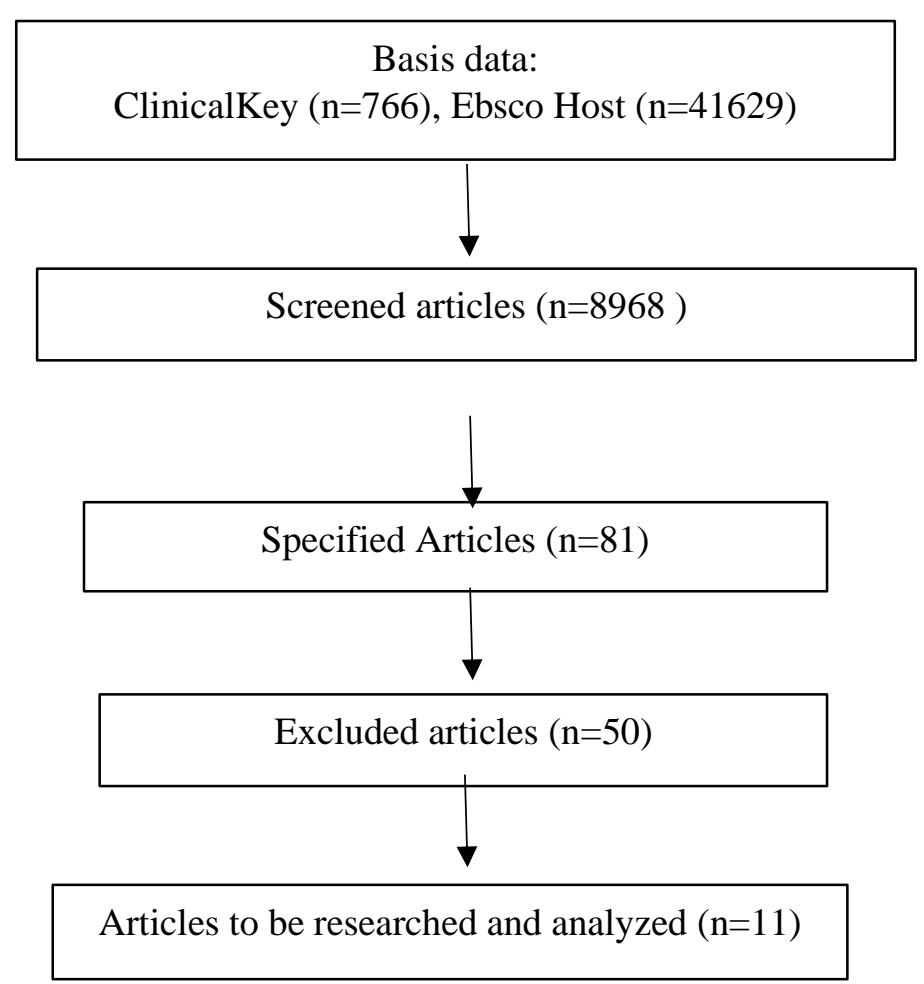
The literature review begins with searching the written material which is considered sequentially from the most relevant, relevant, and sufficiently relevant. Then reading the abstract of each journal first to provide an assessment of whether the problems discussed are in accordance with what is going to be solved in a journal. After that, Noting the important points and their relevance to the research problem. To keep from getting caught in the plagiarism element, the writer should also note the sources of information and include a bibliography. If indeed the information comes from other people's ideas or writing, the writer makes notes, quotes, or information that is arranged systematically so that writing can easily be searched back any time needed (Nursalam, 2016).

For each journal that has been selected based on criteria, a conclusion is drawn that describes the explanation of telenursing in maternity services. Before the writer makes conclusions from several literature results, the writer will identify in a brief summary from a table containing the author's name, year of writing, study design, samples, instruments (measuring instruments), and research results. After the results of writing from some literature have been collected, the writer will analyze the implementation of telenursing in maternity nursing services into the discussion.

\section{Data Analysis Technique}

Research journals that match the inclusion criteria are then collected and a journal summary is made including the name of the researcher, the year of publication of the journal, study design, research objectives, samples, instruments (measuring instruments), and a summary 
of the results or findings. The summary of the research journals is entered into a table sorted according to the alphabet and year of publication of the journal and according to the format mentioned above.

To further clarify the abstract analysis and full text of the journal, it is read and observed. The journal summary is then analyzed for the content contained in the research objectives and the research findings. The analytical method used is using journal content analysis. 


\section{BAB IV}

\section{FINDING AND DISCUSSION}

\section{A. FINDING}

The literature review was conducted to find out that play therapy can reduce anxiety in children by using existing literature collection techniques. The collected literature was analyzed with the Critical appraisal table to answer the objectives of the measurement and compared with the simple measurement results.

\begin{tabular}{|c|c|c|c|}
\hline No & $\begin{array}{l}\text { Play therapy to reduce } \\
\text { anxiety in children } \\
\text { (Title of reviewed } \\
\text { literature) }\end{array}$ & Literature Analysis & $\begin{array}{c}\text { Empirical } \\
\text { Sources }\end{array}$ \\
\hline 1. & $\begin{array}{l}\text { Pengaruh } \\
\text { Bermain }\end{array}$ & $\begin{array}{l}\text { There is an effect of playing } \\
\text { plasticine therapy } \\
\text { (playdough) on changes in } \\
\text { the anxiety of preschool } \\
\text { children (3-6 years) } \\
\text { experiencing } \\
\text { hospitalization. }\end{array}$ & $\begin{array}{l}\text { Alini. (2017). } \\
\text { Jurnal Ners } \\
\text { Universitas } \\
\text { Pahlawan } \\
\text { Tuanku } \\
\text { Tambusai, 1(1), } \\
\text { 1-10. }\end{array}$ \\
\hline 2. & Anxiety In Adolescents. & $\begin{array}{l}\text { Service providers and } \\
\text { medical teams must be } \\
\text { diligent about recognizing } \\
\text { signs of adolescent anxiety } \\
\text { and treating them } \\
\text { immediately. Untreated } \\
\text { anxiety can have detrimental } \\
\text { consequences later on. }\end{array}$ & $\begin{array}{l}\text { Iliana Garcia, } \\
\text { Jean O’Neil } \\
(2021) \\
\text { Journal for } \\
\text { Nurse } \\
\text { Practitioners, } \\
\text { 17(1), 49-53. } \\
\text { https://doi.org/1 } \\
\text { 0.1016/j.nurpra. } \\
\text { 2020.08.021 }\end{array}$ \\
\hline
\end{tabular}


3. Efektivitas Terapi Play therapy (coloring) can Novia, R., \& Bermain (Mewarnai) reduce the level of anxiety in Arini, L. (2021). Terhadap Penurunan hospitalized children. Medihealth: Kecemasan Anak Usia Recommendation for the Jurnal Ilmu Prasekolah (3-6 Tahun) hospital is to provide play Kesehatan Dan Yang Dirawat Di Rumah therapy for hospitalized Sains, 1(1), 41Sakit Harapan Bunda children. Batam.

4. Penerapan Terapi Play therapy (coloring and Parwata, N. M. Bermain Mewarnai Dan origami) can reduce anxiety R. N., \& Origami Terhadap levels in hospitalized Rantesigi, N. Kecemasan Pada Asuhan children.

Keperawatan Anak Dengan Hospitalisasi.

\begin{tabular}{|c|c|c|c|}
\hline & Dengan Hospitalisasi. & & $\begin{array}{l}\text { Nursing Journal, } \\
\text { 1(1), 24-28. } \\
\text { Https://Doi.Org/ } \\
\text { 10.33860/Mnj. } \\
\text { V1i1.292 }\end{array}$ \\
\hline 5. & $\begin{array}{l}\text { Child-Centered Play } \\
\text { Therapy With Young } \\
\text { Children Who Are } \\
\text { Anxious: A Controlled } \\
\text { Trial. }\end{array}$ & $\begin{array}{l}\text { Child-centered play therapy } \\
\text { (CCPT) is effective in } \\
\text { reducing levels of anxiety } \\
\text { and worry }\end{array}$ & $\begin{array}{l}\text { Stulmaker, H. } \\
\text { L., \& Ray, D. C. } \\
\text { (2020). } \\
\text { Children And } \\
\text { Youth Services } \\
\text { Review, 57, } \\
\text { 127-133. } \\
\text { Https://Doi.Org/ } \\
\text { 10.1016/J.Child } \\
\text { youth.2015.08.0 } \\
05\end{array}$ \\
\hline 6. & $\begin{array}{l}\text { Studi Awal Identifikasi } \\
\text { Efek Terapi Bermain } \\
\text { Dengan Lego. }\end{array}$ & $\begin{array}{l}\text { There are psychological } \\
\text { aspects that emerge after } \\
\text { giving play therapy, namely } \\
\text { communication patterns, } \\
\text { cooperation, self-efficacy, } \\
\text { self-confidence, trust in } \\
\text { others, leadership, openness } \\
\text { (Openness to Others), and } \\
\text { creativity }\end{array}$ & $\begin{array}{l}\text { Suryadi, D. } \\
\text { (2017). } \\
\text { Jurnal Muara } \\
\text { Ilmu Sosial, } \\
\text { Humaniora, Dan } \\
\text { Seni, } 1(1), 240 . \\
\text { Https://Doi.Org/ } \\
\text { 10.24912/Jmish } \\
\text { umsen.V1i1.356 }\end{array}$ \\
\hline 7. & $\begin{array}{l}\text { Effectiveness Of A } \\
\text { Group Game } \\
\text { Intervention In Reducing } \\
\text { Preoperative Anxiety } \\
\text { Levels Of Children And }\end{array}$ & $\begin{array}{l}\text { There is an effect of the } \\
\text { game intervention on } \\
\text { preoperative anxiety levels } \\
\text { and there is a significant } \\
\text { reduction in anxiety levels }\end{array}$ & $\begin{array}{l}\text { Ünver, } \quad \text { S., } \\
\text { Güray, Ö., } \quad \text { \& } \\
\text { Aral, S. (2020). }\end{array}$ \\
\hline
\end{tabular}




\begin{tabular}{|c|c|c|c|}
\hline & $\begin{array}{l}\text { Parents: A Randomized } \\
\text { Controlled Trial. }\end{array}$ & & $\begin{array}{l}\text { Https://Doi.Org/ } \\
10.1002 / A o r n .1 \\
2990 \\
\text { Aorn Journal, } \\
403 .\end{array}$ \\
\hline 8. & $\begin{array}{l}\text { Utilization Of Evidence- } \\
\text { Based Treatment Models } \\
\text { At Community-Based } \\
\text { Mental Health Settings } \\
\text { For Young Children } \\
\text { Exposed To Violence. }\end{array}$ & $\begin{array}{l}\text { There are explorations in the } \\
\text { use of treatment models } \\
\text { applied to children exposed } \\
\text { to violence across } \\
\text { community-based clinical } \\
\text { sites and there is a } \\
\text { correlation between the use } \\
\text { of models to child } \\
\text { demographics and the types } \\
\text { of violence experienced by } \\
\text { children. }\end{array}$ & $\begin{array}{l}\text { Urban, T. H., } \\
\text { Nguyen, T. T. } \\
\text { T., Morford, A. } \\
\text { E., Spinelli, T., } \\
\text { Martinovich, Z., } \\
\text { Schewe, P. A., } \\
\text { \& Risser, H. J. } \\
\text { (2020). } \\
\text { Children And } \\
\text { Youth Services } \\
\text { Review, } \\
\text { 116(July), } \\
\text { 105233. } \\
\text { Https://Doi.Org/ } \\
\text { 10.1016/J.Child } \\
\text { youth.2020.105 } \\
\text { 233 }\end{array}$ \\
\hline 9. & $\begin{array}{lr}\text { Cognitive-Behavioral } \\
\text { Play Therapy In Children } \\
\text { Withr } \\
\text { Attachment } \quad \text { Reactive } \\
\text { Help Reduce } & \text { Anxiety, } \\
\text { Impulsivity, } & \text { Bullying } \\
\text { And } & \text { Antisocial } \\
\text { Behaviors. } & \end{array}$ & $\begin{array}{l}\text { There is an effect of play } \\
\text { therapy on cognitive } \\
\text { behavior which significantly } \\
\text { reduces the level of anxiety } \\
\text { and bullying, impulsivity, } \\
\text { and antisocial behavior in } \\
\text { the experimental group. }\end{array}$ & $\begin{array}{lr}\text { Zamani, } & \text { N., } \\
\text { Tavallaei, M., \& } \\
\text { Kahdouei, } & \text { S. } \\
(2020) . & \\
\text { Journal } & \text { of } \\
\text { advanced } & \\
\text { pharmacy } & \\
\text { education } & \text { \& } \\
\text { research } & \\
\text { Vol. 10 } & \text { No.S4 } \\
(115-122) & \end{array}$ \\
\hline 10 & $\begin{array}{l}\text { The Effects Of A } \\
\text { Therapeutic Play/Play } \\
\text { Therapy Program On The } \\
\text { Fear And Anxiety Levels } \\
\text { Of Hospitalized Children } \\
\text { After Liver } \\
\text { Transplantation. }\end{array}$ & $\begin{array}{l}\text { There is an effect of play } \\
\text { therapy on reducing levels } \\
\text { of anxiety and fear in } \\
\text { children }\end{array}$ & $\begin{array}{l}\text { Zengin, Ide, } \\
\text { Hilal Yayan, E., } \\
\text { \& Emin Düken, } \\
\text { M. (2020). } \\
\text { Journal of } \\
\text { Perianesthesia } \\
\text { Nursing Vol. } 36 \\
\text { No. 1 (81-85) } \\
\text { Https://Doi.Org/ } \\
\text { 10.1016/J.Jopan } \\
\text {.2020.07.006 }\end{array}$ \\
\hline
\end{tabular}


Based on the results of the literature review analysis, 10 journals stated that $\mathrm{Ha}$ or the alternative hypothesis is accepted, related to the effect of play therapy on reducing anxiety in children.

The form of ontology, epistemology, and axiology of play therapy, especially in relation to the definition, benefits, and implementation of play therapy in reducing anxiety generally has a positive impact on children. However, there are several variables or notes in the implementation of play therapy to reduce anxiety in each journal that need further discussion.

\section{B. Discussion}

Based on the results of the review of 10 journals, they can be categorized into two groups. The first group is a journal that focuses on the impact or effect of play therapy on reducing anxiety, with as many as five titles. Meanwhile, the second group is a journal that focuses on strategies and media of play therapy applied in reducing anxiety, as many as five titles.

The first group describes that play therapy can reduce anxiety in children. During the corona pandemic, play therapy is present as a safe and comfortable solution for the safety and comfort of patients, especially in children. Play therapy can significantly reduce anxiety levels in children (Saleheh, et al, 2020). In addition, play therapy can also be used to deal with stress and patients with psychological disorders (Laurie, 2020), especially for patients who experience Schizophrenia (Ersa, et al. 2016). In general, the future 
challenge of play therapy is to be an advantage of nursing interventions for children with psychological disorders, especially anxiety.

In the second group, it was described an overview of various strategies and media for implementing play therapy, especially in reducing children's anxiety. Playing is one of the means to stimulate children's growth and development so that they can grow and develop optimally and the play equipment used should be adjusted to the child's age ((Suryadi, 2017). In play therapy, the method used is a cognitive method, namely problem solving by telling stories, which of course is assisted by the aforementioned game tools. The use of play therapy itself is to help children with emotional problems, anxiety due to stress, pressure or depression so that these feelings can be reduced and the children are expected to be able to deal with their problems beforehand. Play therapy can also be implemented into various forms of implementation strategies, including the stage of selecting instruments, the therapy process, the initiation stage or initial sessions of the meeting, the stage of ending the session, seeing client progress, reporting sessions, and completing sessions (Zengin et al., 2020).

After the session ended, it was not the use of peer volunteer assistance or with the help of mothers of children who were experiencing hospitalization, but by looking at some of the strategies and media that have been described and the game tools used should be adjusted to the age of the child and the Covid-19 pandemic period (Suryadi, 2017), the implementation of play therapy is very important in this covid-19 pandemic. There is a potential for developing 
post-pandemic play therapy while paying attention to planning, procedures and processes, as well as careful evaluation (Kimberly, et al. 2020).

Play therapy to reduce children's anxiety can be studied according to ontology, epistemology, and axiology. Ontologically means knowing what exactly the meaning of play therapy is. Play therapy is an approach to provide assistance to overcome problems by using media such as toys, art media, games, and communication (Novia \& Arini, 2021.).

Epistemologically, or how play therapy works, it was stated that play therapy (coloring) can reduce the anxiety of inpatient children. It can provide pleasure and can be used as a medium for channeling feelings as coping for children when the child is hospitalized t (Novia \& Arini, 2021). Feelings of anxiety are the impact of hospitalization experienced by children because they face stressors in the hospital environment and can interfere with the child's growth and development and the healing process. To reduce the anxiety felt by children, games be given.

Axiologically or what exactly play therapy is, it was used for reducing children's anxiety. This service provides benefits, including being able to 1) express thoughts, feelings, fantasies, and creativity while still developing creativity, 2) adapt more effectively to various sources of stress (Garcia \& O'Neil, 2021),3 release the fear and anxiety they experience as coping in the face of stress (Ünver et al., 2020) because the purpose of playing in principle is to be able to continue the phase of growth and development optimally, and 4) reflect, have self-introduction through a deep experience process with 
playing media such as houses, dolls, animal figures, and others (Ortiz et al., 2020). 


\section{CHAPTER V}

\section{CLOSING}

\section{A. Conclusion}

Based on the results of reviews conducted in 10 journals, it can be concluded that play therapy is an approach to assist in overcoming problems using media such as toys, art media, games, and communication. Play therapy can have a positive impact on expressing thoughts, feelings, fantasies, and creative power by continuing to develop creativity and adapting more effectively to various sources of stress, especially in dealing with children's anxiety problems. Furthermore, play therapy can be developed both during a pandemic and post-pandemic, by utilizing a variety of strategies and media. Research and development of play therapy are carried out by paying attention to aspects of planning to evaluation so that it is in accordance with existing conditions both during the pandemic and post-pandemic.

\section{B. Recommendation}

\section{For Nurses}

It is hoped that nurses can take advantage of play therapy to provide interventions in reducing the anxiety of all patient characteristics, not only in children but also others by still maintaining the covid-19 health protocol in the new-normal era so that the health of nurses and patients continues to improve.

2. For Researchers 
This literature review can be used as a source of research data for further research which is carried out based on other factors, different variables, and locations or situations. 


\section{BIBLIOGRAPHY}

Alini. (2017). Pengaruh Terapi Bermain Plastisin (Playdought) Terhadap Kecemasan Anak Usia Prasekolah (3-6 Tahun) Yang Mengalami Hospitalisasi Di Ruang Perawatan Anak Rsud Bangkinang Tahun 2017. Jurnal Ners Universitas Pahlawan Tuanku Tambusai, 1(1), 1-10.

Garcia, I., \& O'neil, J. (2021). Anxiety In Adolescents. Journal For Nurse Practitioners, 17(1), 49-53. Https://Doi.Org/10.1016/J.Nurpra.2020.08.021

Novia, R., \& Arini, L. (2021). Efektivitas Terapi Bermain (Mewarnai) Terhadap Penurunan Kecemasan Anak Usia Prasekolah (3-6 Tahun) Yang Dirawat Di Rumah Sakit Harapan Bunda Batam. Medihealth: Jurnal Ilmu Kesehatan Dan Sains, 1(1), 41-52.

Ortiz, R., Banca, L., Carolina De Moraes Brandão, M., De, V., Sparapani, C., Santini De Souza, N., Neves, T., Gabriela, M., Cavicchioli, S., Garcia De Lima, A., \& Castanheira Nascimento, L. (2020). A Fun Way To Learn About Diabetes: Using Therapeutic Play In A Brazilian Camp. Journal Of Pediatric Nursing. Https://Doi.Org/10.1016/J.Pedn.2020.02.002

Parwata, N. M. R. N., \& Rantesigi, N. (2020). Penerapan Terapi Bermain Mewarnai Dan Origami Terhadap Kecemasan Pada Asuhan Keperawatan Anak Dengan Hospitalisasi. Madago Nursing Journal, 1(1), 24-28. Https://Doi.Org/10.33860/Mnj.V1i1.292

Stulmaker, H. L., \& Ray, D. C. (2015). Child-Centered Play Therapy With Young Children Who Are Anxious: A Controlled Trial. Children And Youth Services Review, 57, 127-133. Https://Doi.Org/10.1016/J.Childyouth.2015.08.005

Suryadi, D. (2017). Studi Awal Identifikasi Efek Terapi Bermain Dengan Lego®. Jurnal Muara Ilmu Sosial, Humaniora, Dan Seni, 1(1), 240. Https://Doi.Org/10.24912/Jmishumsen.V1i1.356

Ünver, S., Güray, Ö., \& Aral, S. (N.D.). Effectiveness Of A Group Game Intervention In Reducing Preoperative Anxiety Levels Of Children And Parents: A Randomized Controlled Trial. Aorn Journal, 403. Https://Doi.Org/10.1002/Aorn.12990

Urban, T. H., Nguyen, T. T. T., Morford, A. E., Spinelli, T., Martinovich, Z., Schewe, P. A., \& Risser, H. J. (2020). Utilization Of Evidence-Based Treatment Models At Community-Based Mental Health Settings For Young Children Exposed To Violence. Children And Youth Services Review, 116(July), 105233. Https://Doi.Org/10.1016/J.Childyouth.2020.105233

Zamani, N., Tavallaei, M., \& Kahdouei, S. (2020). Cognitive-Behavioral Play Therapy In Children With Reactive Attachment Disorder: Help Reduce Anxiety, Impulsivity, Bullying And Antisocial Behaviors. Journal Of Advanced Pharmacy Education \& Research, 10(S4), 115-122.

Zengin, Ide, Hilal Yayan, E., \& Emin Düken, M. (2020). The Effects Of A 
Therapeutic Play/Play Therapy Program On The Fear And Anxiety Levels Of Hospitalized Children After Liver Transplantation. Https://Doi.Org/10.1016/J.Jopan.2020.07.006 